\title{
Israeli Practices of Governance in Palestine
}

\author{
ELIA ZUREIK \\ Queen's University, Canada \\ ORCID No: 0000-0003-4615-5043
}

\begin{abstract}
By the standards of historical and anthropological scholarship, Israel constitutes a colonial settler regime whose certain features may differ from those exhibited by other European settler regimes. Yet, in the larger scheme of things it shares with other such regimes the displacement of the indigenous population, seizure of their territory, the passing of racially biased laws that discriminate against the native population, and reliance on violence to further its methods of control. Originally, the Zionist movement and later the state of Israel have frustrated the aspirations of the Palestinian people towards statehood. Ultimately, the state of Israel has codified its new Citizenship Law that defines Israel as the state of the Jewish people, thus ignoring the status of the original Palestinian population.
\end{abstract}

Keywords: Israel, Palestine, Governance, Settler Colonialism, Citizenship Law, Zionism 


\section{Introduction}

D $y$ the end of 2019, the Palestinian Census Bureau put the global number D of Palestinians worldwide at 13.35 million of whom 5.03 million live in the occupied territories of the West Bank and Gaza, and 1.597 million reside in Israel, 5.96 million live as refugees in neighboring Arab countries, and the remaining 0.727 million reside in other parts of the world. ${ }^{1}$ The Jewish population of Israel was estimated at the end of 2017 as 6.9 million, 0.5 million of whom were settlers living in the occupied territories. ${ }^{2}$ Therefore, the balance of Jews and Arabs living between the Jordan River and the Mediterranean Sea, covering the entire territory of historical Palestine that is now controlled by Israel, stood at 6.9 million Jews compared to 6.5 million Arabs. From the point of view of population balance, the numbers of Jews and Arabs constitute parity and before too long they are expected to attain equal numbers.

\section{Settler Colonialism as a Form of Apartheid}

It is not fashionable nowadays to speak of colonialism, since it is considered an archaic $18^{\text {th }}$ or $19^{\text {th }}$ century passing phenomenon. Its staying power, however, is revealed in its essential features. Colonialism, which was part of the past, nevertheless also remains part of the postcolonial present, as geographer Derek Gregory points out. ${ }^{3}$ It is manifested in the way it treats and controls the native population, in the panoply of its racialist laws, and its routine reliance on and use of instruments of violence. By its very nature colonialism is not a static phenomenon, as anthropologist Patrick Wolfe rightly emphasizes. It is an ongoing process and not an event. ${ }^{4}$ Its structure is in constant evolution aiming to achieve its ultimate objectives. Israel, as a settler colonial state, provides an apt illustration of the process.

Land ownership is the cornerstone of any colonial edifice. It is clear from the Israeli Basic Law of 1951 that once the land is defined as Jewish, it shall remain so in perpetuity and its ownership cannot be transferred to any groups or individuals. This stance has recently been codified in legislation by the new Nationality Law, which was enacted in July 2018. It spelled out in more detail the implications of the new law for the status of the Palestinian minority in Israel.

Critical analysis of this nation-state Law is informed by a theoretical framework that is anchored in the settler-colonial perspective. The main components of the Law include downgrading the status of the Arabic language in the country, pointing out that Israel is the state of the Jewish people, thus ignoring the fact that demographically there are almost as many non-Jews as Jews living in historical Palestine under Israeli control, and that national self-determination is the prerogative of the Jews only. Furthermore, a related aspect of the 
law is that in its declarative capacity Israel is established 'in the land of Israel rather than on it'. What flows from this, in the absence of defined borders, is that the law leaves open the possibility that future state borders could extend beyond the current ones. Finally, immigration leading to automatic citizenship is open only to Jews. Prime Minister Benjamin Netanyahu lauded the law for signaling a "defining moment" in Israel's history, at a time when Palestinian citizens in Israel, who comprise 20 percent of the population, referred to it as a new "apartheid" law that treats them as second-class citizens. ${ }^{5}$

Amal Jamal, a political scientist at Tel Aviv University, offered contextual analysis of the law that, in his view, reveals the state's "exclusive ethno-theological values" and "settler-colonial ideology and practices." The law transformed the relationship between the state and the Palestinians (citizens and non-citizens), the Druze minority (of which he is a member), and the secular Jewish left. The old hegemonic elites represented by Ashkenazi Jews were supplanted by new hegemonic elites that are drawn from the extreme right in Israel. Under this law, the relationship between the Jewish state and the Palestinians has been mutated from "one based on contested disparity into a relationship of landlords and aliens." Moreover, "The Palestinians -citizens and non-citizens- are constructed not only as occasional inhabitants, but also as foes, whose fate is total surrender or death." The Druze, on the other hand, who early in the state's history succumbed to the divide and rule principle, subscribed to the notion that they were intrinsically different from the local Arab population, and their co-opted traditional leaders agreed for the Druze to be inducted into compulsory service in the army. Thus, according to Jamal, those who had "mistakenly thought of themselves as occupants of a privileged status akin to the Jews, found themselves outside the Jewish tribal nexus, as defined by the new law." The third group that was negatively affected by the new law is what Jamal calls liberal Jewish leftists "who are accused of betraying their national commitments by expressing loyalty to universal civic values." This is a loaded statement that is contested by the Palestinians. It is not clear that these universal civic values have been translated into solidarity with the Palestinians in their daily struggles. ${ }^{6}$

For Ahmad Sadi, a Palestinian Arab academic at Ben Gurion University, the new law reveals modern Zionism's efforts at obfuscating its real intentions towards Palestine and the Palestinians by adopting in its discourse what is called constructive ambiguity. Throughout its modern history Zionism talked about reconciliation with the Palestinians and sharing the land with them. The racist 


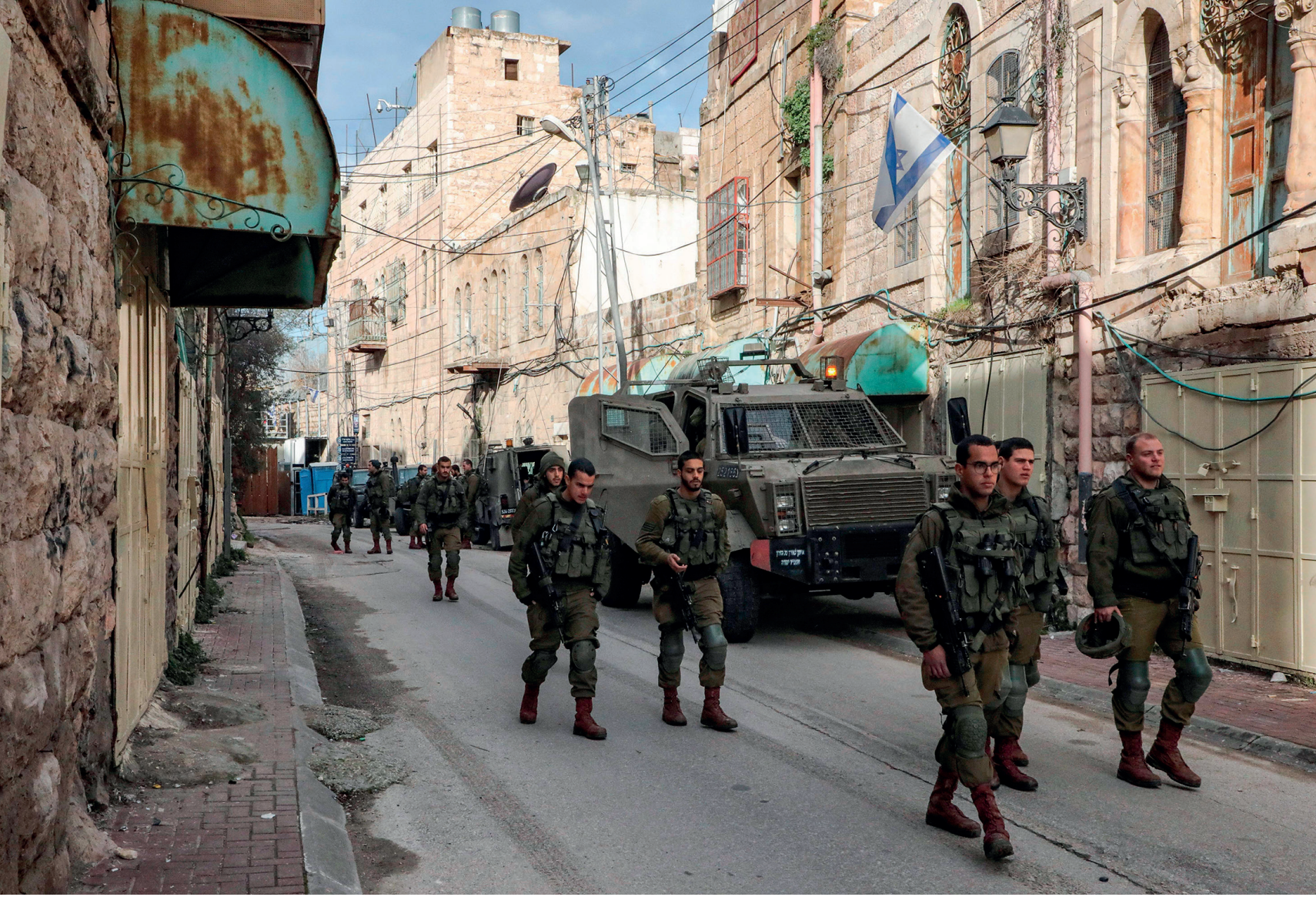

Israeli soldiers patrolling in

Shuhada Street, in the city of Hebron, a flashpoint in the occupied West Bank, January 28

2020.

HAZEM BADER / AFP via Getty Images

language of the new law reveals that there is nothing further from the truth. All along, Zionism has been engaged in a "deceptive" language to disguise its true intentions at dispossessing the Palestinians through settler colonialism. ${ }^{7}$

In 2017, the United Nations (UN), through its Economic and Social Commission for Western Asia (ESCWA), issued a bold report that traced the evolution of Israeli occupation of Palestinian territories into a structure of apartheid. ${ }^{8}$ The conclusion of the report states that Israel has established an apartheid regime that dominates the Palestinian people as a whole. Aware of the seriousness of this allegation, the authors of the report conclude that available evidence establishes beyond a reasonable doubt that Israel is guilty of policies and practices that constitute the crime of apartheid as legally defined in instruments of international law.

Bearing in mind that in 1948, at the time of the establishment of Israel, not more than 7 percent of the land constituting historical Palestine was legally Jewish-owned, and this was after concerted efforts by Jewish settlers and Zionist organizations that received at the time the blessing of the British Mandatory government to induce the native Palestinians to sell their land. Arab land ownership now is estimated around 7 percent, a lopsided transformation of the original land ownership. How this came about is not a mystery.

The ESCWA Commission faced at the outset accusations from the Zionist lobby and its supporters that its report suffers from anti-Semitic bias, among other 
things. This response is expected when Israel is exposed for its inhumane treatment of the Palestinians. Rather than recapitulate the defense mounted by the United Nations agency, I shall summarize briefly the thrust of the report's arguments. The definition of apartheid rests on the 1973 Apartheid Convention and includes "similar policies and practices of racial segregation and discrimination as practiced in southern Africa, [and] shall apply to... inhuman acts committed for the purpose of establishing and maintaining domination by one racial group of persons

At best, the Palestinians in Israel are treated as a "suspect community," and those in the occupied territories are considered a surplus population to be surveilled by the state's various institutions and the Jewish public over any other racial group of persons and systematically oppressing them." The report argues that for the charge of apartheid to apply, the case should reflect "intent of racial discrimination" on the part of the responsible government, Israel in this case. The report finds substantiation of both intent and purpose of Israeli practices. The report points out that (i) according to Israeli Basic Law (the Constitution) discriminatory policies have ensured the ownership of 96 percent of the land of historical Palestine as Jewish in perpetuity; (ii) Israel practiced through its laws what the report calls "demographic engineering," whereby citizenship is conferred automatically on every Jew that immigrates to Israel, "while withholding any comparable right from Palestinians, including those with documented ancestral homes in the country;" and (iii) "the strategic fragmentation of the Palestinian people is the principal method by which Israel imposes an apartheid regime." It appears to the writers of the report that prolonged occupation and the fragmentation of the Palestinian territories provide the Israeli state with tools to buttress its hegemony over the Palestinians. This fragmentation gives rise to the application of different sets of laws depending on where the Palestinians live and whether they are refugees, residents of Jerusalem, or otherwise. As stated in the report " $t]$ his fragmentation operates to stabilize the Israeli regime of racial domination over the Palestinians and to weaken the will and capacity of the Palestinian people to mount a unified and effective resistance. Different methods are deployed depending on where Palestinians live." ${ }^{10}$ Thus, the report concludes in its executive summary that fragmentation into various domains "[c]onstitutes one comprehensive regime developed for the purpose of ensuring the enduring domination over nonJews in all land exclusively under Israeli control in whatever category." ${ }^{11}$

\section{Palestinians in Israel's Political Culture}

Throughout its history, the Palestinians in Israel were treated as a marginal group in political life, even though after the expulsion of the majority of them 


\section{The Trump Administration, which is the most recent enabler of illegal Israeli international conduct in Palestine and elsewhere, has broken every conceivable modicum of statesmanship}

in 1948 they constituted only 20 percent of the population. As such, they are excluded from defining the public good.

Public opinion polls and statements by Israeli leaders show that disregard for Palestinian life has characterized the attitudes of Israeli authorities and the Jewish public at large towards its Arab citizens and those who live in the West Bank and Gaza. For Israel, the Palestinians constitute what the Italian philosopher Giorgio Agamben calls "homo sacer," according to which the laws of humanity do not apply to them. ${ }^{12}$. The Palestinians exist in conditions of "bare life." Their minimal existence is tolerated but not enhanced. Invariably, the law is suspended when it comes to rectifying Palestinian grievances. Israel is usually quick to cite "national security" as justification for its lethal actions against the Palestinians. Life for Palestinian citizens of the state as well as those who live in the occupied territories is in a perpetual state of emergency where exceptions to the universal application of the law, is the rule. As a colonial settler state, life in Israel, according to Ronit Lentin, is best viewed from a racialist prism where ethnicity and race govern the treatment of those it controls. ${ }^{13}$ As in all colonial regimes, violence, territory and population are the three central elements which occupy the colonizer, and Israel is no exception.

We have many examples to testify to Israel's sub-human treatment of the Palestinians. For example, Dov Weissglasse, who had been Israel's point man in advising successive Israeli prime ministers on policy towards the Palestinians, described the choking off of the food supply and other essential goods to Gaza's population during the 2014 invasion of Gaza as akin to a "diet regime." He quipped cynically: "It is like an appointment with a dietician. The Palestinians will get a lot thinner but won't die." 14 Rafael Eytan, a former Israeli Chief of Staff, referred to the Palestinians as "cockroaches in a bottle." ${ }^{15}$ Former Prime Minister Menachem Begin called them "two-legged beasts."16 The previous Shas party leader suggested that God should send the Palestinian "ants" to hell and called them "serpents." ${ }^{17}$ Furthermore, in August 2010, the Sephardic Chief Rabbi Ovadia Yosef pronounced that "God should strike" the Palestinians "with a plague." ${ }^{18}$ Dan Schueftan, a professor at Tel Aviv University, wrote in the newspaper Maariv in October 2009 that "the Arabs are the biggest failure in the history of human race. There's nothing under the sun that's more screwed up than the Palestinians." 19 Thus, at best, the Palestinians in Israel are treated as a "suspect community," and those in the occupied territories are considered a surplus population to be surveilled by the state's various institutions and the Jewish public. 
The Zionist project remains in full throttle and in line with the dreams of the founders of the state; its current and future leadership will not rest until the Palestinian presence in Israel and the West Bank and Gaza is significantly reduced. The Trump Administration, which is the most recent enabler of illegal Israeli international conduct in Palestine and elsewhere, has broken every conceivable modicum of statesmanship. President Donald Trump has unilaterally moved the U.S. embassy from Tel Aviv to Jerusalem, cut off the funding of the UNRWA, a UN agency that was created in 1948 to cater for Palestinian refugees, closed down the PLO office in Washington D.C., sanctioned the illegal annexation of the Syrian Golan Heights by Israel for its use, and welcomed the dishonor bestowed upon him by accepting a so-called gift from Netanyahu in the shape of a village to be named after him on the Syrian Golan Heights. Most recently, Trump revealed the long-awaited plan for Middle East peace that was rejected out of hand by the Palestinians for its flagrant bias in favor of Israel, and, finally, Michael Pompeo, Trump's Secretary of State, went on record earlier in January condoning Israel's illegal seizure of Palestinian lands on the West Bank for the purpose of building Zionist settlements.

The latest two elections in Israel in 2019 were inconclusive from the point of view of the Zionist parties. They ushered in a third election to be held in March 2020. These cases provide examples of marginalization of the Arabs in Israel's political life. Netanyahu is on the cusp of being the longest serving prime minister in Israel's history. As it turned out his Likud Party finished with one Knesset seat behind Benny Gantz's Blue and White Coalition (32 seats to 33), and altogether, the latter mustered 54 seats, one more seat than the former. Israel's President gave Netanyahu the first opportunity to form a government. The Arab-dominated Joint List surprised the pundits by emerging as the third largest party with 13 seats in the 120 Knesset seats. The Balad Party, a member of the coalition in the Arab Joint List, declared that they would not serve with Gantz because, as the Chief of Staff of Israel's army, he had launched a brutal military campaign in Gaza five years ago and refused to repeal the recent Nationality Law, which was viewed as racist and discriminatory against the Palestinian minority. As a result, they withdrew their support of Gantz. Those remaining in the Joint List offered to lend support to Gantz should he be called upon to form the next government, but, as head of the List stated in a New York Times opinion piece, "without joining his expected national unity coalition government." ${ }^{20}$ The upshot of this is that Gantz did not call upon the Joint Arab List.

Although Netanyahu has not returned as an outright winner, his political stamina remains a formidable ideological weapon on the Israeli political scene. If the past is any indication, no doubt the Israeli public has not seen the end of "Bibi" (Netanyahu's nickname). However, before he contemplates a political comeback, he must answer the charges of corruption revolving around bribery, fraud, and breach of trust. ${ }^{21}$ 


\section{Netanyahu the Populist}

When discussing the current "wave of populism" sweeping the globe, there are certain names one expects to hear-Donald Trump, Marine Le Pen, Geert Wilders, or "Brexit." Benjamin Netanyahu is not among them, but perhaps he should be. ${ }^{22}$

Is Benjamin Netanyahu, the Prime Minister of Israel, a precursor or follower of the alt-right movement that is making itself felt in North America and is sweeping certain European capitals and Third World countries? How can one explain Netanyahu's affinity to Third World dictators, ultra-nationalists, populists, the Evangelical Christian Zionists, and the extreme political right in what is nominally labeled liberal democracies or aspiring democracies? As will be

For Israel, it is not only ideology that is a common element among this group [of populists], there is intense lucrative commercial activity in selling arms and cyber technology to unsavory regimes shown below, this is not a surprising manifestation of newly discovered, kindred ideologies. Rather, it reflects Netanyahu's ideological commitment to Revisionist Zionism all along.

Israel's past diplomatic isolation on the international stage is rooted foremost in its attitudes to the Palestine question and failure to reach an agreement with the Palestinians on statehood after signing the Oslo Accords. More than half a century has passed with Israel in full military control of the West Bank, while its blockade of Gaza has relegated the Strip to the status of utter despair and poverty. The last two decades have seen a reversal in the alignment of nations towards Israel. When in the past the Third World and the East European Communist bloc supported the Palestinians in their struggle for a state, Western Europe and the U.S. provided Israel with diplomatic cover and financial backing. The $21^{\text {st }}$ century saw a major reversal: although the U.S. remained steadfast in its support of Israel, Third World countries, which now include certain Arab states, are lining up to pay homage to Israel's prowess, while key liberal Western European states, as well as the European Union, distanced themselves from the right-wing policies of Israel under Netanyahu..$^{23}$

Political scientists Pippa Norris and Ronald Inglehart defined populism as distrustful of all elites and institutions, from scientists to the news media. It views 'ordinary people' as homogeneous and inherently 'good' or 'decent.' Diversity, in this view, compromises that purity. While these tenets feel democratic to proponents, they form a vision of democracy that is majoritarian rather than pluralistic. That majority -'the people'-can be defined by race or religion or class, but there is always someone left out. ${ }^{24}$ 


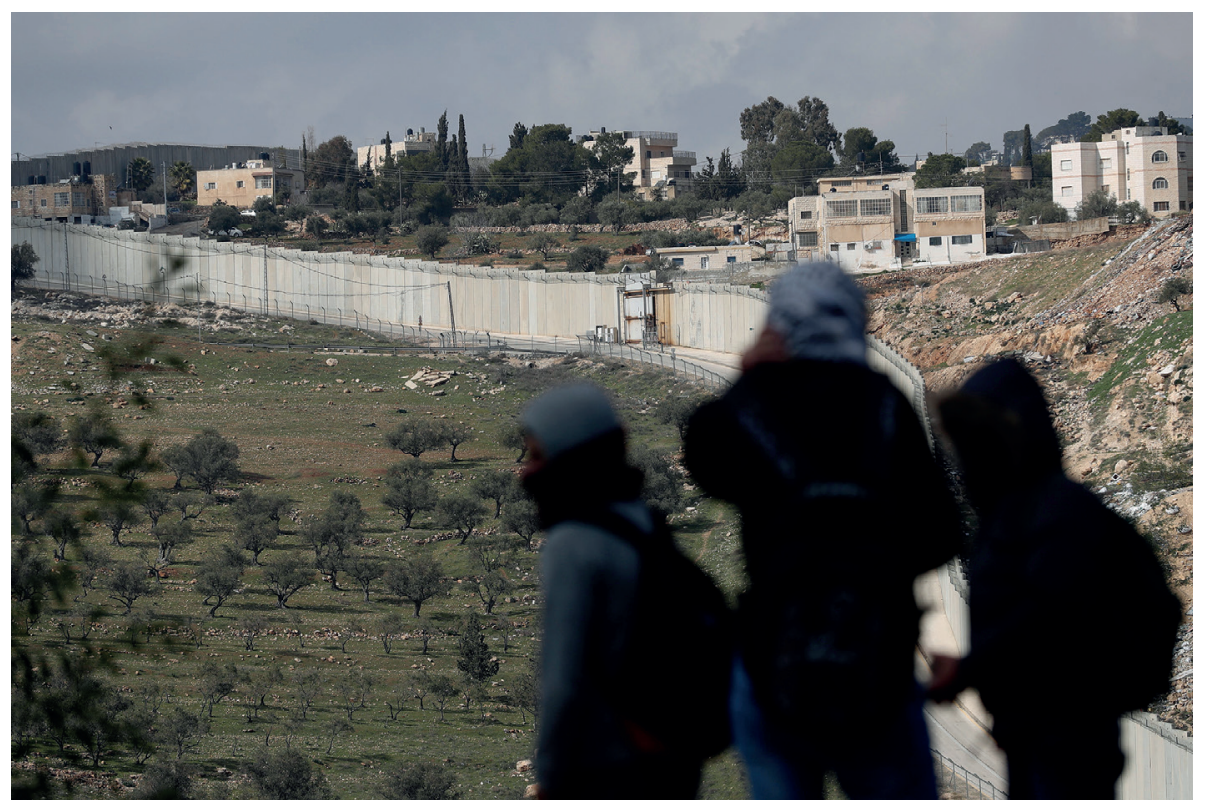

In the words of The Economist, Netanyahu's followers call him "The Magician," "The Winner," and "The King of Israel." Although he is embroiled in charges of corruption, he "matters because he embodied the politics of muscular nationalism, chauvinism and the resentment of elites long before such populism became a global force," and he "counts among his friends and allies such nationalists as Donald Trump and Narendra Modi of India, not to mention European ones from Viktor Orbán in Hungary to Matteo Salvini in Italy." ${ }^{25}$ Ben Judah added to the list Rodrigo Duterte of the Philippines, Jair Bolsonaro of Brazil, and Mohammed bin Salman of Saudi Arabia. ${ }^{26}$ In the words of Robert Kegan, "Netanyahu has curried the favor of various majoritarian, nationalist, illiberal rulers around the world, from India to Russia to Hungary to the Oval Office." 27

Netanyahu embraced a coterie of authoritarian dictators as allies. He ignored Hungary's authoritarian policies, Orbán's anti-Semitic tendencies and his attacks on liberalism, including on George Soros, a Jewish liberal economist of Hungarian background. Israeli officials worked hard to open Trump's Oval Office to Orbán after he was shunned by Barack Obama. Likewise, Netanyahu interceded on behalf of Russian President Vladimir Putin to soften the American sanctions against Russia for annexing Crimea and interfering in the U.S. elections. He welcomed to Israel the dictator President Duterte of the Philippines, who likened himself to Adolf Hitler. ${ }^{28}$ The nationalist government in Poland has passed a bill that outlawed attempts to label Poland's past collusion against the Jews during Hitler's reign. In the words of the bill, the Polish state outlawed assigning "responsibility or co-responsibility to the Polish nation or
Young Palestinians stand along Israel's separation wall, in the occupied West Bank village of Abu Dis, which has been designed as the new Palestinian capital in U.S. President Donald Trump's plan for the Middle East, January 29, 2020. EMMANUEL DUNAND / AFP via Getty Images 
Zionist settlers remain committed to expanding their hold on Palestine by seizing more territory: with Trump's blessing, Israel has annexed the Syrian Golan Heights, refused to relinquish its control of the Jordan Valley, and continues to expand its illegal settlements in the West Bank state for crimes committed by the German Third Reich." ${ }^{29}$ Netanyahu was quick to call on Trump urging him to overlook the accusations leveled against the Saudi Crown Prince Mohammed bin Salman for his involvement in the gruesome murder of the Saudi journalist Jamal Khashoggi in 2018.

The Palestinian Arab citizens in Israel have been subjected to scorn and racist incitements by Netanyahu who saw them threatening his Likud dominance by heading in "droves" to the election booth to unseat him. He lobbied unsuccessfully to install cameras in election halls to document an alleged Palestinian fraudulent voting. ${ }^{30}$ Although Netanyahu was taken by Trump, it is too simple to describe him as Trump's political imitator. As one commentator remarked, Netanyahu was on the ultra-nationalist path long before Trump appeared on the political scene. ${ }^{31}$ When it comes to anti-Semitism, Kagan points out, Trump played the role of an enabler. ${ }^{32}$

A rising tide of white nationalism in the United States has accompanied Trump's rise to office, and this has included an increase in the incidence of anti-Semitism, including, in some cases, violent anti-Semitism. Trump's equivocal response $\mathrm{e}^{33}$ to the violent confrontation in Charlottesville -at which participants in a "Unite the Right" rally chanted "Jews will not replace us!"- showed that, at the very least, he was unwilling to repudiate the anti-Semites among his followers. When Israeli officials stood up for Trump after the Pittsburgh synagogue shooting ${ }^{34}$ last year, because, as one official explained, ${ }^{35}$ "the guy has been a huge friend" to Israel, many American Jews questioned whether the Israeli government cared about their concerns. ${ }^{36}$

An international coalescing of populist right wing leaders is crystalizing. Netanyahu established a working relationship with Donald Trump, Boris Johnson, Rodrigo Duterte, Jair Bolsonaro, Narendra Modi, Viktor Orbán, Matteo Salvini, Alexander Vučić, and Mateusz Morawiecki. For Israel, it is not only ideology that is a common element among this group, there is intense lucrative commercial activity in selling arms and cyber technology to unsavory regimes. ${ }^{37}$

Some commentators point out that this signals an ominous sign for liberal democracies. A recent news report states: 
In Israel, Prime Minister Benjamin Netanyahu, a close Trump ally, complained of a "witch hunt" launched by his rivals as the country's attorney general pursues possible corruption charges against him. In Britain, Prime Minister Boris Johnson -who came to power this year via the votes of a fraction of a fraction of the British public- smeared members of Parliament thwarting Brexit as agents of "surrender" and "betrayal." In India, the world's biggest democracy, the country's Hindu nationalist leaders routinely cast their rivals as "anti-national" liberals who ought to move to Pakistan. ${ }^{38}$

Evidence bearing on the above claims came during the recent pretrial hearings of Netanyahu. A mob of sympathizers picketed the Attorney General's home in support of Netanyahu. Another group of Netanyahu supporters consisting of right wing elites warned of the "deep state" created by the machinations of 'left wing plotters' against Netanyahu. Being the consummate populist, legal commentators point out that Netanyahu's main audience is public opinion and not the courts. ${ }^{39}$

Due to the similarity in temperaments and political strategies, journalists depicted Trump and Netanyahu as "political twins." Both are described as polarizing and divisive figures facing legal investigations involving criminal charges. Both reacted by attacking the judiciary, the police, the so-called "hostile media" for spreading "fake news," and leftist critics, while calling the investigations they face a "witch hunt." Their trusted allies are family members, social media, and working-class supporters (the Mizrahim in Israel, and blue-collar workers in the U.S.). ${ }^{40}$

However, one Israeli newspaper has recently stated that "Netanyahu and Trump are no longer bosom buddies." ${ }^{41}$ This came at the start of Trump's impeachment investigation by the U.S. House of Representatives. While Netanyahu was counting the Likud seats in the September elections that fell short of a majority, Trump amplified his response of ignoring Netanyahu by saying that he supports Israel the country and not any individual as such.

\section{"Deal of the Century"}

Finally, the "deal of the century" regarding the establishment of a Palestinian state, as it is labeled by Trump, was revealed by the White House in late January 2020. This is the brainchild of Jared Kushner, Trump's son in law and senior advisor. Kushner, who lacks any credible credentials on the Middle East, is rather known for his strong Zionist commitments and his backing of the settlement project on the West Bank. ${ }^{42}$ Present in the audience for the occasion from the Arab world were three peripheral states, Oman, Bahrain, and the UAE; absent were the Palestinians and the remaining Arab states. 


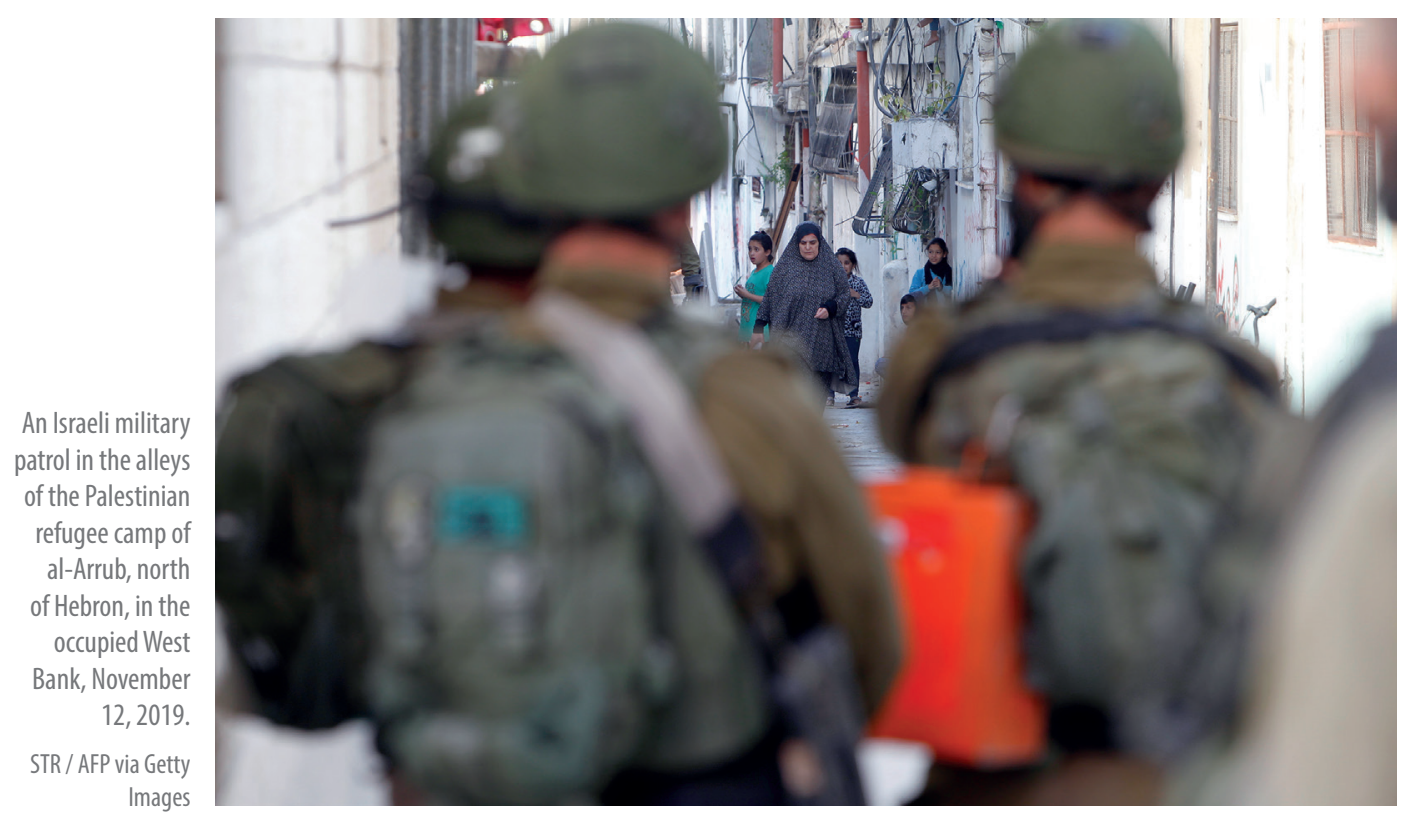

The proposal rewards Israel by giving it all of Jerusalem to be its "united capital" forever, maintaining the illegal Jewish settlements in the West Bank, controlling the Jordan Valley, moving the Palestinian residents from border towns in Israel to the Palestinian entity, and stripping them of their Israeli citizenship. Under the plan, the Palestinians will forfeit 30 percent of the West Bank which to begin with constituted 28 percent of Palestine's area. Finally, the West Bank will be a demilitarized where Israel remains the sole military force in the area. ${ }^{43}$ The reaction of those who had labored in the past at resolving the conflict was to describe the flawed proposal as biased and favoring Israel in its details. ${ }^{44}$

According to pundits, the rationale behind making public the details of the proposal for resolving the conflict between the Palestinians and Israel at that particular time was because of the pressing politics surrounding Trump and Netanyahu personally. Both were in the middle of trials on corruption charges, and revealing the plans for resolving the Middle East conflict could be a convenient distraction from their woes. As for Trump, he also hoped to boost his popularity among American Jews who were not terribly enthralled by his domestic stance.

\section{Conclusion}

The Palestine tragedy was one of the most enduring upheavals of the twentieth century. After more than a century, there is no sign that the conflict be- 
tween the Zionist settlers and the Palestinian people is about to end. If anything, Zionist settlers remain committed to expanding their hold on Palestine by seizing more territory: with Trump's blessing, Israel has annexed the Syrian Golan Heights, refused to relinquish its control of the Jordan Valley, and continues to expand its illegal settlements in the West Bank.

The Palestinians face formidable obstacles when dealing with Israel. First, they suffer from a weak economy which according to the World Bank and Gaza GDP is estimated on a per capita basis to be

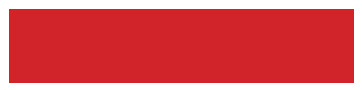

These internal divisions enable Israel to govern and exercise control over the Palestinians with impunity $\$ 3,710$ for the West Bank and Gaza combined for 2018, compared to $\$ 41,715$ for Israel for $2018 .{ }^{45}$ Second, militarily there is no comparison between Israel and the Palestinians. The former possesses one of the largest air forces in the World and a modern well-equipped standing army, while the latter has hardly any military force to speak of. Third, the Palestinians are not expecting tangible assistance from other Arab countries some of whom are consumed with an Iranian threat and internal Arab state conflicts that are engulfing Syria, Libya, and Yemen. Finally, internal divisions are further fragmenting the Palestinian camp in its attempt to present a unified front against Israel. These internal divisions enable Israel to govern and exercise control over the Palestinians with impunity. Trump's release of the Middle East peace plan is an utter disappointment to the Palestinians. There is very little in it for them. It might as well have been written by Israel itself.

\section{Endnotes}

1. Ola Awad, "A Brief on the Status of Palestinian People at the End of 2019," The Palestinian Central Bureau of Statistics, (December 31, 2019), retrieved from http://pcbs.gov.ps/site/512/default.aspx?tabID $=512 \&$ lang $=$ en\&ltem $I D=3642 \&$ mid=3171\&wversion=Staging.

2. Khaled Abu Toameh, "Palestinian Census: 4.7 Million in West Bank and Gaza Strip," The Times of Israel, (March 28, 2018), retrieved from https://www.timesofisrael.com/palestinian-census-4-7-millionin-west-bank-and-gaza-strip/.

3. Derek Gregory, The Colonial Present, (Malden MA, Oxford England, and Victoria Australia: Blackwell Publishing, 2004). See also, Lorenzo Veracini, The Settler Colonial Present, (London: Palgrave Macmillan, 2015).

4. Patrick Wolfe, "Settler Colonialism and the Elimination of the Native," Journal of Genocide Research, Vol. 8, No. 4 (December 2006), pp. 387-409.

5. Miriam Berger, "Israel's Hugely Controversial 'Nation State' Law Is Explained," Vox, (July 31, 2019).

6. Amal Jamal, "Israel's New Constitutional Imagination: The Nation-State Law and Beyond," Journal of Holy Land and Palestine Studies, (Fall 2019), p. 195.

7. Ahmad Sa'di, "The Nation State Law of the Jewish People's Basic Law: A Threshold of Elimination?" Journal of Holy Land and Palestine Studies, (Fall 2019), p. 165. 
8. Richard Falk and Virginia Tilley, "Israeli Practices towards the Palestinian People and the Question of Apartheid," United Nations Economic and Social Commission for Western Asia (ESCWA), (2017), retrieved from https://electronicintifada.net/sites/default/files/2017-03/un_apartheid_report_15_march_english_final_.pdf.

9. Falk and Tilley, "Israeli Practices," p. 1.

10. Falk and Tilley, "Israeli Practices," pp. 4-5.

11. Falk and Tilley, "Israeli Practices," p. 6.

12. Giorgio Agamben, Homo Sacer: Sovereign Power and Bare Life, (Stanford, CA: Stanford University Press, 1998). The homo sacer, in Roman law, is defined legally as someone who can be killed without the killer being regarded as a murderer; and a person who cannot be sacrificed.

13. Ronit Lentin, Traces of Racial Exception: Racializing Israeli Settler Colonialism, (London: Bloomsbury Academic, 2018).

14. Elia Zureik, "Colonialism, Surveillence, and Population Control: Israel/Palestine," in Elia Zureik, David Lyon, and Yasmeen Abu-Laban (eds.), Surveillence and Control in Israel/Palestine: Population, Territory and Power, (Oxford: Routledge, 2011), p. 33.

15. Odeh Biisharat, "The Fate of the Arabs: Like Drugged Cockroaches in a Bottle," Haaretz, (Februray 6, 2018).

16. Elia Zureik, Israel's Colonial Project in Palestine: Brutal Pursuit, (Oxford and New York: Routledge, 2016), p. 88.

17. Zureik, Israel's Colonial Project in Palestine, p. 88.

18. “Shas Spiritual Leader: Abbas and Palestinians Should Perish," Haaretz, (August 29, 2010).

19. Richard Silverstein, "Dan Schueftan: Senior Israeli Arab Analyst, Confidant of Generals and Prime Ministers, and Arab Hater," Tikun Olan, (November 6, 2009), retrieved from https://www.richardsilverstein.com/2009/11/06/dan-schueftan-senior-israeli-arab-analyst-advisor-to-generals-and-prime-ministers-and-racist/.

20. Ayman Odeh, "The Leader of the Joint List of Predominantly Arab Parties Explains Why It Will Use Its Power to Help Make Benny Gantz Prime Minister of Israel," The New York Times, (September 22, 2019); See also, Isabel Kershner, "Netanyahu's Amazing Reversal: Election Loser to Presumptive Premier," The New York Times, (September 26, 2019). For the statement of head of the Balad Party in the Joint Arab List, see, "Why as Balad We Did not Recommend Gantz as Israel's Next Prime Minister," Haaretz, (September 26, 2019).

21. At the time of the writing this article, the Knesset formally started its investigation into Netanyahu's conduct. The prognostication is that if convicted Netanyahu will serve a prison term.

22. Jonathan G. Leslie, "Netanyahu's Populism: An Overlooked Explanation for Israeli Foreign Policy," SAIS Review of International Affairs, Vol. 37, No. 1 (Winter-Spring 2017), pp. 75-82.

23. Consider, for example, a recent incident at the United Nations in which Israel's envoy lashed out at a spokesman of the Israeli human rights organization B'Tselem, himself an Israeli, who was invited to speak at a Security Council session. France, Britain, the Netherlands, and Sweden sent a letter protesting the behaviour of the Israeli envoy who called the B'Tselem speaker "a collaborator.." See, Itamar Eichner, "European Countries Criticize Israel's UN Envoy," Ynetnews.com, (October 31, 2018).

24. Max Fisher, "When a Political Movement Is Populist, or Isn't," The New York Times, (May 10, 2017).

25. "King Bibi: Benyamin Netanyahu A Parable of Modern Populism," The Economist, (March 30, 2019), Print Edition.

26. Ben Judah, "Bibi Was Right," The Atlantic, (December 18, 2018). For a thorough analysis of Netanyahu's ideology, see, Robert Kagan, "Israel and the Decline of the Liberal Order," The Washington Post, (September 12, 2019).

27. Kagan, "Israel and the Decline of the Liberal Order." 
28. Karen Lema and Manuel Mogato, "Philippines' Duterte Likens Himself to Hitler, Wants to Kill Millions of Drug Users," Reuters, (September 30, 2016).

29. "Netanyahu Slams 'Outrageous' Holocaust Remark by Polish PM in Munich," thelocal.de, (February 18, 2018).

30. Toi Staff, "Responding to Sa'ar petition, Netanyahu Backs Cameras in Likud Polling Stations," Times of Israel, (December 17, 2019).

31. Daniel Estrin, "Israeli Prime Minister Benjamin Netanyahu Is Waging a Mudslinging Re-election Campaign on Social Media, Channeling His Close Ally President Trump in Style and Substance," National Public Radio, (April 1, 2019.)

32. Kagan, "Israel and the Decline of the Liberal Order."

33. "President Donald Trump on Charlottesville: You Had Very Fine People, on Both Sides," CNBC, (August 15, 2017), retrieved from https://www.youtube.com/watch?v=JmaZR8E12bs.

34. Campbell Robertson, Christopher Mele, and Sabrina Tavernise, "11 Killed in Synagogue Massacre; Suspect Charged With 29 Counts," The New York Times, (October 27, 2018), retrieved from https://www. nytimes.com/2018/10/27/us/active-shooter-pittsburgh-synagogue-shooting.html.

35. Mark Landler, "Trump Finds Support After the Pittsburgh Massacre, From the Israeli Government," The New York Times, (November 1, 2018), retrieved from https://www.nytimes.com/2018/11/01/us/politics/trump-visits-pittsburgh-shooting-israel.html.

36. Kagan, "Israel and the Decline of the Liberal Order."

37. According to the Stockholm International Peace Research Institute, Israel is ranked $8^{\text {th }}$ globally among exporters of arms. See, Pieter d. Wezeman, et al., "Trends in International Arms Transfer," SIPRI, (March 2018), retrieved from https://www.sipri.org/sites/default/files/2018-03/fssipri_at2017_0.pdf.

38. Ishaan Tharoor, "Trump's Impeachment Battle Is Part of a Bigger Global Crisis in Democracy," The Washington Post, (October 4, 2019).

39. Ruth Margalit, "The Precarious Position of Benjamin Netanyahu," The New Yorker, (October 8, 2019).

40. Loveday Morris and Ruth Eglash, "Under Investigation and up for Re-Election, Netanyahu's Kinship with Trump Has Never Been Clearer," The Washington Post, (March 19, 2019).

41. Orly Azulay, "Netanyahu and Trump Are No Longer Bosom Buddies," Ynetnews.com, (September 24, 2019).

42. Elia Zureik, "Donald Trump's Punitive Politics and the Question of Palestine: A Gaze into Trump's Psyche and Foreign Policy" Journal of the Holy Land and Palestine Studies, , Vol. 18, No. 2 (Fall 2019), pp. 139-162.

43. Oliver Holmes, et al., "Trump Unveils Middle East Peace Plan with No Palestinian Support," The Guardian, (January 28, 2020).

44. Kori Schake, "A Middle East Peace Plan Built on Un-American Principles," The Atlantic, (June 3, 2019).

45. "GDP per Capita (current US\$) - Israel," The World Bank, retrieved from https://data.worldbank.org/ indicator/NY.GDP.PCAP.CD?locations=IL. 


\section{EUROPEAN ISLAMOPHOBIA REPORT 2018}

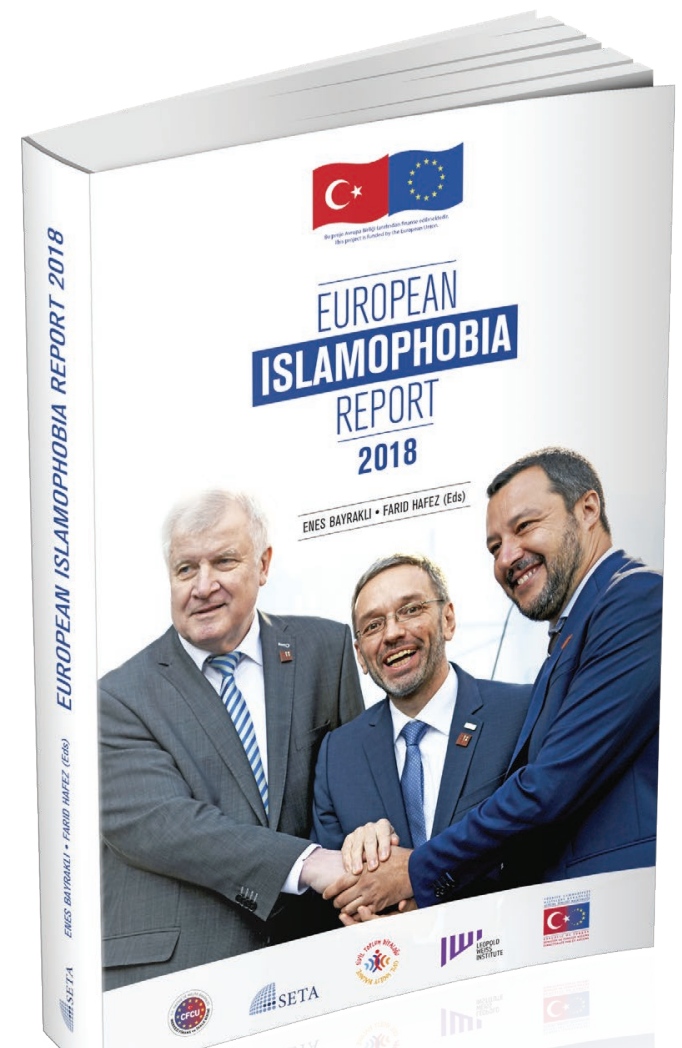

By ENES BAYRAKLI • FARID HAFEZ (Eds.)

The fourth annual European Islamophobia Report (EIR) scrutinizes the developments of Islamophobia in 34 European countries for 2018

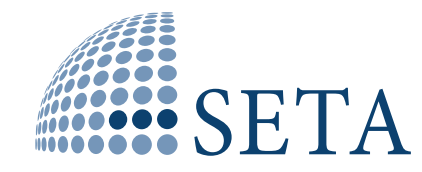

